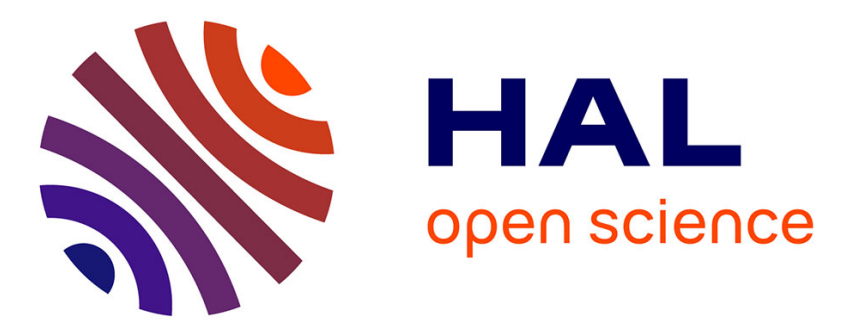

\title{
Successional patterns on tropical inselbergs: a case study on the Nouragues inselberg (French Guiana)
}

Corinne Sarthou, Charlotte Kounda-Kiki, Anne Vaçulik, Philippe Mora, Jean-François Ponge

\section{To cite this version:}

Corinne Sarthou, Charlotte Kounda-Kiki, Anne Vaçulik, Philippe Mora, Jean-François Ponge. Successional patterns on tropical inselbergs: a case study on the Nouragues inselberg (French Guiana). Flora, 2009, 204 (5), pp.396-407. 10.1016/j.flora.2008.05.004 . hal-00494625v2

\section{HAL Id: hal-00494625 \\ https://hal.science/hal-00494625v2}

Submitted on 22 Jul 2015

HAL is a multi-disciplinary open access archive for the deposit and dissemination of scientific research documents, whether they are published or not. The documents may come from teaching and research institutions in France or abroad, or from public or private research centers.
L'archive ouverte pluridisciplinaire HAL, est destinée au dépôt et à la diffusion de documents scientifiques de niveau recherche, publiés ou non, émanant des établissements d'enseignement et de recherche français ou étrangers, des laboratoires publics ou privés. 
1 Successional patterns on tropical inselbergs: a case study on the Nouragues

2 inselberg (French Guiana)

3

4 Corinne Sarthou ${ }^{1}$, Charlotte Kounda-Kiki ${ }^{1}$, Anne Vaçulik ${ }^{1}$, Philippe Mora ${ }^{2}$ and Jean-

$5 \quad$ François Ponge ${ }^{1 *}$

6

$7{ }^{1}$ Muséum National d'Histoire Naturelle, CNRS UMR 7179, 4 avenue du Petit-Château,

891800 Brunoy, France; e-mail ponge@mnhn

$9 \quad{ }^{2}$ Université Paris-XII, IRD UMR 137 BioSol, 61 avenue du Général-de-Gaulle, 94010

10 Créteil Cédex, France

11

$12 *$ Corresponding author

13

14 E-mail addresses of the authors:

15

16 C. Sarthou: sarthou@mnhn.fr

17 C. Kounda-Kiki: c.kounda-kiki@laposte.net

18 A. Vaçulik: annevaculik@yahoo.fr

19 P. Mora: mora@univ-paris12.fr

20 J.F. Ponge: ponge@mnhn.fr 


\section{Abstract}

2

A number of plant communities have been described on tropical inselbergs,

4 known as hot spots of plant and animal biodiversity. However, few studies tried to

5 question what drives seral processes in these harsh environments, submitted to natural

6 hazards (violent storms, intense runoff, lightning strikes) which may destroy the

7 vegetation cover and its accumulated organic matter. We analysed quantitative data

8 from the granitic Nouragues inselberg (French Guiana) in order to discern how

9 successional processes featured their variety. We showed that the transition from

10 herbaceous carpets (bromeliaceous mats and grassy meadows) to woody vegetation

11 (shrub thickets) was not conditioned by slope but was truly successional. We also

12 showed that there was a cycle of change in shrub thickets, reinitiated by the destruction

13 of scrub vegetation by fire (lightnings), wood-destroying fungi and termites.

15 Keywords: Granite; Non-equilibrium Coexistence; Rocky outcrops; Small scale 16 disturbance

\section{Introduction}

Tropical inselbergs (rocky outcrops protruding from a plain landscape) are hot

21 spots of plant and animal biodiversity, due to the high turnover of species between sites

22 and the presence of organisms almost restricted to the inselberg habitat (Gasc et al.,

23 1998; Porembski et al., 2000a; Sarthou et al., 2003). They are characterized by isolated

24 patches of vascular vegetation surrounded by bare rock or cryptogamic vegetation

25 (Sarthou et al., 1995; Büdel et al., 2000). The great diversity of slope and aspect 
1 conditions and the high contrasts in temperature and humidity on the bare rock are

2 prone to the development of particular adaptive strategies (Porembski et al., 2000b;

3 Biedinger et al., 2000; Sarthou, 2001) which confer to inselbergs a high biodiversity

4 conservation value (Parmentier, 2005).

Some studies described distinct plant communities on inselbergs without any

7 attempt to classify them into seres (Sarthou and Villiers, 1998; Parmentier, 2003;

8 Parmentier et al., 2005; Oumorou and Lejoly, 2003), while others aimed at discerning

9 successional pathways (Hambler, 1964; Shure and Ragsdale, 1977; Ibisch et al., 1995;

10 Larpin et al., 2000). Dispersal limitation, stochastic processes and past vegetation

11 changes due to climatic fluctuations explain strong disceprancies in floristic

12 composition from an inselberg to another, and between parts of the same inselberg,

13 despite basic similarities in biological traits of dominant plant species (Sarthou and

14 Villiers, 1998; Sarthou et al., 2003; Parmentier et al., 2005). All these features make

15 difficult to assess successional processes by synchronous analysis, each inselberg or

16 even part of an inselberg being unique in its botanical composition.

The present study was a case study, aimed at disentangling the complex successional processes which occur on the Nouragues inselberg (French Guiana), both by putting things in order in a set of vegetation samples by multivariate analysis and by

21 observing and sketching the establishment and death of dominant plant species.

Methods

\section{Study area}


The Nouragues inselberg $\left(4^{\circ} 3^{\prime} \mathrm{N}, 52^{\circ} 42^{\prime} \mathrm{W}\right.$, maximum altitude $\left.410 \mathrm{~m}\right)$ is located

3 in French Guiana (South America), $100 \mathrm{~km}$ south of the Atlantic Coast in the tropical

4 rain forest, a region with a very low level of anthropogenic disturbance (Fig. 1). It is

5 included in the Balenfois Mountains near the Arataye river, in the Nouragues Biological

6 Reserve. It is dome-shaped, of the so-called whaleback type (Bremer and Sander, 2000).

7 Geomorphological features include flat surfaces, steep slopes, depressions and gullies

8 (Fig. 2A). The very old rocky substrate (2.1-2.6 giga-years) belongs to the granodiorite

9 series originating from the Trans-Amazonian orogenesis (Gruau et al., 1985; Théveniaut

10 and Delor, 2004), with smooth pellicular erosion (exfoliation) due to high thermic

11 contrasts and chemical dissolution of plagioclases and potassic feldspars (Sarthou and

12 Grimaldi, 1992). Coarse (1-2 mm) quartz grains, detached from the substratum by

13 mineral weathering, accumulate in small, closed depressions or are flushed away by

14 intense run-off. Scales of granite are exfoliated by differential dilatation and slowly

15 slide down the smooth, convex slopes (Hurault, 1963), leaving edges onto which

16 pioneer plants (Bromeliaceae, Clusiaceae) may fasten at the time of germination.

Mean annual precipitation reaches $3250 \mathrm{~mm}$, with a dry season from July to

19 November and a wet season from December to June, interrupted by a very short dry 20 season in March (Sarthou and Villiers, 1998). The air temperature (screened condition) 21 varies daily from 18 to $55^{\circ} \mathrm{C}$ and the air moisture varies from 20 to $100 \%$ (Sarthou, 22 1992). The temperature measured directly on the bare rock may reach $75^{\circ} \mathrm{C}$ in the dry 23 season. Most of the surface is covered by cyanobacteria (Sarthou et al., 1995), which 24 take part in mineral weathering and fix carbon and nitrogen (Sarthou and Grimaldi, 25 1992). Cyanobacteria, like lichens on inselbergs in drier regions (Büdel et al., 1997), are 
1 the primary factor in the establishment of nutrient cycles on rock surfaces. Vascular

2 vegetation, locally called 'rock savanna' (English translation of 'savane-roche'), is

3 made up of scattered patches of herb and shrub communities, but steep slopes are

4 covered only with cryptogamic vegetation (Fig. 2A). Organic soils (1-20 cm depth),

5 acid ( $\mathrm{pH}$ 4.0-5.5), with a high faunal and microbial activity, are formed under patches of

6 woody vegetation where humified organic matter is prevented from flushing by a dense

7 root network (Sarthou and Grimaldi, 1992; Kounda-Kiki et al., 2006). The summit of

8 the inselberg, and the ecotone zone surrounding it, are covered with a low forest rich in

9 epiphytes and understory plants (Larpin, 2001).

11 'Epilithic' plant communities have been described on the Nouragues inselberg

12 (Sarthou, 1992; Sarthou and Villiers, 1998; Sarthou, 2001; Sarthou et al., 2003). The

13 common development of soil and vegetation has been studied by Sarthou and Grimaldi

14 (1992), Vaçulik et al. (2004) and Kounda-Kiki et al. (2006, 2008). We will focus our

15 story on the vascular vegetation of 'rock savanna', omitting fringe and summit forested

16 areas. 'Rock savanna' can be found in (i) a summit plateau called 'Summit' (Fig. 2A),

17 rolling gently in south direction, sloping mostly from 0 to $15 \%$ (but slopes higher than

$1820 \%$ are also present), (ii) a lower terrace called 'Les Terrasses' (Fig. 2A), with slopes

19 mostly between 15 and $40 \%$, (iii) a small savanna ( $\sim$ ha) included within a forested

20 area occupying a terrace on the north-east face of the inselberg, called 'Savane Coco',

21 with gentle slopes, mostly less than $10 \%$. More water flows on lower terraces than on

22 the summit plateau, due to topographical drainage.

24 Vegetation samples 
Vegetation data were taken from previously published studies which described

2 in detail the sampling procedure (Sarthou and Villiers, 1998; Sarthou, 2001; Sarthou et

3 al., 2003). Briefly, vegetation was sampled on the three parts of the inselberg covered

4 by savanna rock, over three consecutuve years, from November 1987 to November

5 1989. The plot size varied from $4(2 \times 2 \mathrm{~m})$ to $8 \mathrm{~m}^{2}(2 \times 4 \mathrm{~m})$ according to patch size in 50

6 disjointed areas covered by herbaceous vegetation, and was fixed to $16 \mathrm{~m}^{2}(2 \times 8 \mathrm{~m})$ in

757 disjointed areas covered by woody vegetation. These areas were selected in order to

8 represent the whole variation in vegetation observed on the inselberg. Cover abundance

9 data were recorded according to the Braun-Blanquet approach (Braun-Blanquet, 1964)

10 then transformed into a numerical scale according to Van der Maarel (1979). Plant

11 species were grouped into growth forms. Mosses and cyanobacteria were registered as

12 present or absent, but were not considered at the species level. Slope and soil depth

13 were measured at the centre of each plot, by using a goniometer and forcing a steel rod

14 down to the granite, respectively.

16 Multivariate analysis

18 Vegetation data were subjected to correspondence analysis (CA), a multivariate

19 method allowing the simultaneous projection of samples and species in a set of factorial

20 axes (Greenacre, 1984). The main (active) variables were the 74 plant species recorded

21 in the plots (Table 1). Additional (passive) variables, describing community parameters

22 (species richness, growth forms), cryptogamic vegetation (mosses, cyanobacteria),

23 environmental conditions (slope, presence of free water, soil depth) and position of

24 plant samples on the inselberg ('Summit', 'Les Terrasses', 'Savane Coco') were

25 projected on factorial axes together with the main variables. Plant species were 
1 classified into growth form groups. For each sample and for each growth form group we

2 summed up the cover values of corresponding plant species. All variables (main and

3 additional) were reweighted and refocused according to Greenacre (1984) in order to (i)

4 avoid discrepancies between contributions to factorial axes and factorial coordinates,

5 (ii) allow quantitative, qualitative and semi-quantitative variables of varying scale to be

6 included in the same analysis. As a consequence, all plant species had the same weight

7 (mean $\mathrm{m}$ fixed to 20 and standard deviation $\mathrm{s}$ fixed to 1 by tranforming $\mathrm{x}$ into $\mathrm{X}=(\mathrm{x}-$

$8 \mathrm{~m}) / \mathrm{s}$ ) and thus were at the same distance of the origin in the factorial hyperspace. Plant

9 species were doubled into lower and higher values (of cover value) in order to discern

10 also trends of increasing abundance and richness of the community (Peltier et al., 1997).

11 For that purpose, to each plant species (X, mean 20, variance 1), to be projected among

12 samples were it is more abundant, was added a conjugate variable, with same mean (20)

13 and variance (1), measuring the non-occurrence of this species $\left(X^{\prime}=40-X\right)$. Note that it

14 is quite common, when dealing with large data matrices (here 182 rows and 107

15 columns), that the first CA factorial axes extract only a little part of the total inertia,

16 which does not preclude them to be highly informative in terms of ecological trends

17 (Benzécri, 1969).

19 Results and discussion

The numerical analysis of vegetation samples

CA showed three groups of varying botanical composition (Figs. 3A, B), as 24 already described previously (Sarthou and Villiers, 1998). Axis 1 (16\% of the total inertia) separated herbaceous vegetation (left side of the horizontal axis), with 
1 Utricularia hispida (UHI) as most characteristic, from woody vegetation (right side of

2 the same axis) with Clusia minor (CMI) as most characteristic. Cyanobacteria, mosses,

3 herbs (annual and perennial) and suffrutex were associated with herbaceous vegetation,

4 while shrubs, trees, climbers and hemiparasites were associated with woody vegetation

5 (Fig. 3A). Note that rosettes, by their position not far from the origin along Axis 1, were

6 common to both herbaceous and woody vegetation. More plant species were present in

7 patches of woody vegetation (16-22 species per sample), compared to herbaceous

8 vegetation (5-10 species), as ascertained by the projection of the two extreme categories

9 of species richness on both sides of Axis 1, the intermediate category (11-15 species)

10 being projected not far from the origin. This can be explained by the smaller size of

11 herbaceous plots $\left(4\right.$ to $8 \mathrm{~m}^{2}$ ) compared to woody plots $\left(16 \mathrm{~m}^{2}\right)$. The slope did not

12 explain the variation in botanical composition depicted by Axis 1, because the three

13 classes of slope were projected not far from the origin along this axis, but differences

14 were found according to the geographical position of the samples. Herbaceous

15 vegetation was dominant in 'Savane Coco', and to a lesser extent in 'Les Terrasses'

16 while woody vegetation was dominant in 'Summit'. At first sight this could be thought

17 to be an artifact of sample plot selection, however it actually reflected the distribution of

18 vegetation types on the inselberg (Sarthou, 1992). The three vegetation types were

19 present in 'Summit', while only shrub and bromeliaceous vegetation was present in 'Les

20 Terrasses' and only bromeliaceous vegetation in 'Savane Coco' (Fig. 3A).

Axis 2 of total CA (6\% of the total inertia) separated two groups within 23 herbaceous vegetation, the one on the positive (upper) side of this axis, with Pitcairnia geyskesii (PGE) as most characteristic, the other on the negative (lower) side, with

25 Axonopus ramosus (ARA) as most characteristic (Figs. 3A, B). The upper group 
1 (bromeliaceous mats) was comprised of rosettes, cyanobacteria, annuals, suffrutex and

2 creeping perennial herbs, while the lower group (grassy meadows) was comprised of

3 erect perennial herbs and mosses (Fig. 3A). Free water (water running periodically on

4 the granite) was associated with bromeliaceous mats. Axis 2 showed also a gradient

5 within woody vegetation (right side of Axis 1), opposing trees and climbers (with the

6 highest number of plant species) in the lower part of Axis 2 to rosettes and

7 hemiparasites in the upper part of this axis, but this trend was poorly reflected in the

8 botanical composition, as shown by the fact that plant species were grouped in an

9 intermediate position (Fig. 3B), pointing on quantitative rather than qualitative changes

10 in cover values of plant species within woody patches. Contrary to Axis 1, the slope

11 varied along Axis 2, gentle slopes being projected on the lower (negative) part (grassy

12 meadows, woody thickets with trees) while steep slopes were projected on the upper

13 (positive) part of this axis (bromeliaceous mats, woody thickets without trees but with

14 rosettes). As expected, gentle slopes (and corresponding samples) were mostly

15 represented in 'Summit' (negative side of Axis 2) while steep slopes were mostly

16 represented in 'Les Terrasses' (positive side of Axis 2).

The combined effects of slope and succession

On slopes, some vegetation clumps dominated by P. geyskesii (bromeliaceous

21 mats) were enriched in C. minor, while some vegetation clumps dominated by C. minor

22 (shrub thickets) were enriched in P. geyskesii. If we examine the respective cover values

23 of $P$. geyskesii and C. minor in samples taken on medium and steep slopes (by

24 excluding slopes up to $10 \%$ ) it appears that the shrub C. minor can be found at a low

25 cover value in bromeliaceous carpets dominated by P. geyskesii, even when the cover 
1 value of the latter is at its maximum (9), and that the frequency of C. minor increases as

2 far as the cover value of P. geyskesii decreases from 9 to 7 (Fig. 4). At a cover value of

37 for P. geyskesii, C. minor can be found either at a lower cover value of 2 (thus as in

4 bromeliaceous mats dominated by P. geyskesii) or at a higher value of 8 , i.e. at the value

5 commonly observed in shrub thickets, where the cover value of $P$. geyskesii can be

6 observed to decrease step-by-step from 7 to 0 . This points to a successional process by

7 which the herb rosette $P$. geyskesii can be replaced by the shrub C. minor on slopes.

8 Given that vegetation sampling was done over fixed rectangular areas, the qualitative

9 information on the architecture of vegetation clumps is lacking in our numerical

10 analysis. Fig. 2B pictures the common occurrence of concentric rings of P. geyskesii

11 around vegetatively expanding clumps of $C$. minor. On the same photograph, a young

12 individual of C. minor can be seen established within a bromeliaceous carpet (to the

13 left), while an older individual of the same shrub species can be seen creeping

14 downslope on the right side. Both P. geyskesii and C. minor were seen to establish by

15 seed directly on the granite, but a nurse effect of the former in favour of the latter is

16 highly probable. The spatial relationships of these two species within thickets growing

17 on slopes have been sketched in Fig. 5.

The peripheral exclusion of light-demanding herbs by shrubs expanding their crowns is a well-known process (Watt, 1955) which can be discerned easily on the

21 Nouragues inselberg. However, we may wonder whether the enrichment of shrub 22 thickets in woody and climber species, as depicted by Axis 2 of CA (Fig. 3) is truly 23 successional or due to decreasing slope, as suggested by CA. If we discard samples 24 taken on gentle slopes, the cover value of $P$. geyskesii in woody vegetation was 25 negatively correlated $\left(\mathrm{r}_{\mathrm{s}}=-0.50, \mathrm{P}<0.01, \mathrm{n}=26\right)$ with the number of woody species. 
1 This points to an increasing variety of shrubs, trees and woody climbers as far as the

2 abundance of $P$. geyskesii decreases, when slope was not allowed to vary. When

3 analysing the whole set of samples of woody vegetation $(n=57)$, simple regression

4 analysis showed that slope did not account for the number of woody species $(t=-0.993$,

$5 \quad \mathrm{P}=0.33)$ while the abundance of $P$. geyskesii did $\left(\mathrm{t}=-3.69, \mathrm{P}=5.10^{-4}\right)$. Although we

6 cannot discard without eradication experiments a possible interference of $P$. geyskesii

7 with the establishment of woody species, the most plausible hypothesis is that the

8 establishment of shrubs, trees and climbers within clumps of $C$. minor causes the retreat

9 of prostrated light-demanding species such as P. geyskesii.

Small gap disturbances occurring within C. minor thickets might be the way by which they become colonized by a more diversified woody flora, among which Myrcia sylvatica (Myrtaceae) is most frequently observed. At the border of shrub thickets

14 (mostly upslope) patches $\left(1-10 \mathrm{~m}^{2}\right)$ can be seen devoid of living woody vegetation, with an accumulation of dead wood, still standing or transformed into humus and covered 16 with mosses (Fig. 2C). A closer examination of advancing zones of destruction reveals 17 intense wood-rotting and xylophagous termite activity (Fig. 2D) and charcoal has been 18 found in all samples taken in the topsoil of destruction zones (Kounda-Kiki et al., 2008).

19 Whether wood-destroying fungi and xylophagous termites occur concurrently after fire

20 (due to lightning strikes) or, more probably, according to a substrate succession starting 21 with death of woody branches and stems and subsequent fungal development, is still a 22 matter of conjecture, but we always found rotten wood associated with termite consumption. In areas where aerial parts of C. minor have been destroyed in this way,

24 the ground is often covered with a cryptogamic vegetation made of mosses and/or 25 lichens (Fig. 2C), the rhizoids of which are known to prevent soil particles to be flushed 
1 away by water (Leach, 1931). However, other places can be seen without any

2 cryptogamic vegetation, maybe as an earlier stage of colonization. This exposes the root

3 system of C. minor, which locally dies in the absence of a vegetation cover. The

4 establishment by seed of phanerogamic vegetation can be observed in such places when

5 they are protected from intense runoff (Fig. 2E). Laterally, destruction zones, when not

6 rapidly penetrated by moss and lichen rhizoids, can be easily flushed away, exposing

7 the granitic substrate at a place previously occupied by vegetation. Zones destroyed by

8 fire, fungi and termites are bordered by a species-rich ecotone where herbaceous and

9 woody species cohabit (Fig. 2F), pointing to their role in the botanical enrichment of $C$.

10 minor thickets. The advance of succession can thus be seen as a cyclical process when

11 and where a primary sere is reinitiated on bare granite or an 'helicoidal process' when

12 and where the organic soil accumulated under woody vegetation increases in thickness

13 at each cycle of building and destruction.

Fig. 3 shows an opposition between the Bromeliaceae P. geyskesii and the

16 Poaceae A. ramosus along Axis 2 of CA. Axis 2 was explained by slope, which

17 discriminated between negative and positive sides of this axis and A. ramosus was 18 mainly present on slopes $\leq 10 \%\left(\mathrm{t}=-3.89, \mathrm{P}=3.10^{-4}\right)$. If we take into account only

19 gentle slopes (thereby excluding the effect of slope), there appears a positive 20 relationship between the cover value of $A$. ramosus and soil depth $\left(\mathrm{t}=19, \mathrm{P}<10^{-4}\right)$, and 21 a negative relationship with the cover value of $P$. geyskesii $\left(\mathrm{r}_{\mathrm{s}}=-0.71, \mathrm{P}=5.10^{-8}\right)$, 22 which was itself negatively influenced by soil depth $\left(\mathrm{t}=-26, \mathrm{P}<10^{-4}\right)$. Soil (mostly 23 sand and gravel issuing from the weathering of granite) was shown to accumulate in 24 small depressions periodically filled up by water during storms, more especially near 25 the summit of the inselberg ('Summit'). These results point to a successional process, 
1 governed by the increase in thickness of the mineral soil in the absence of slope. Here,

2 too, $P$. geyskesii was observed to grow in concentric rings around A. ramosus meadows

3 but in this case the spatial discrimination was due to the epilithic behaviour of the

4 bromeliad, maybe reinforced by some interference with A. ramosus. Several Cyperaceae

5 (Rhynchospora fallax, Rhynchospora tenella, Rhynchospora subdicephala, Scleria

6 cyperina) have been shown to accompany A. ramosus. At a micro-scale we observed

7 that the deposition of gravel and sand was not uniform but rather formed a mosaic with

8 Cyperaceae growing in gravelly parts of the depressions while A. ramosus grew in

9 sandy parts. The interplay between the segregated deposition of mineral particles by

10 water flushes, the immobilization of sand within the basal parts of sedges and the clonal

11 growth of $A$. ramosus is at the origin of a parallel development of soil and vegetation

12 which has been sketched in Fig. 6 as described by Sarthou (1992). Depressions may

13 become invaded by $C$. minor, which establishes both by seed and vegetatively, thus

14 starting the development of woody vegetation, with associated soil formation $(8-20 \mathrm{~cm})$,

15 depressions becoming finally enclosed in Clusia thickets.

This successional scheme does not explain how early as well as late seral stages are still observable on the inselberg. Before deeper, more stable soils are formed under

19 the development of woody vegetation, a return to early stages of vegetation

20 development can be effected by a flush effect during violent storms, destructing

21 sand/gravel deposits with their accompanying vegetation. An alternative explanation

22 could be the formation of dissolution pans on flat parts of the granite, but the slow rate at which such depressions may form in granite makes this hypothesis highly improbable

24 (Hurault, 1963; Bremer and Sander, 2000). 


\section{Comparisons with other inselbergs}

2

4 5

6 Meirelles et al., 1999). In West Africa, monospecific mats of the sedge Afrotrilepis

7 pilosa (W.C. Boeck) J. Raynal have been widely reported (Hambler, 1964; Jeník and

8 Hall, 1976; Parmentier, 2001, 2003; Oumorou and Lejoly, 2003). Their seral

9 development exhibits many features in common with bromeliaceous mats, although

10 they seem to be much more stable (Hambler, 1964; Porembski et al., 1996).

Several authors described primary plant successions on exposed granite in temperate regions, especially in the United States (Whitehouse, 1933; Oosting and Anderson, 1939; Keever et al., 1951; Burbanck and Platt, 1964; Burbanck and Phillips, 1983). In their dynamic schemes, lichens are pioneer organisms which weather the rock and constitute microsites favouring seedling establishment. These authors insisted on the slow rate of the observed successional processes and the absence of any equilibrium in the establishment of the late-successional 'shrubby' stage. They showed that the high mortality rate of woody plants was due to dry conditions and instability of the soil substrate, the local disappearance of the final stage initiating a new cycle of vegetation dynamics. Shure and Ragsdale (1977) studied a primary succession on a granitic outcrop in Georgia (USA), involving both plant and soil animal communities, but they did not question the reasons for the absence of a forested stage. Parmentier (2003), studying three inselbergs in Central Africa, did not describe any woody vegetation except summit and fringe forest areas. Jeník and Hall (1976) and Oumorou and Lejoly 
1 (2003) described woody plant communities on slopes of inselbergs in West Africa, but

2 they attributed the existence of woody areas to thickness of the soil which, based on our

3 own observations, should not be considered as a cause but rather as a consequence of

4 shrub development (Vaçulik et al., 2004; Kounda-Kiki et al., 2006). Hambler (1964)

5 and later Isichei and Longe (1984) described the seral and seasonal development of

6 Afrotrilepis mats on Nigerian inselbergs, but without any appearance of woody

7 vegetation except in particular areas such as ravines and fringes of the summit forest,

8 probably because of recurrent fires during the dry season. However Ibisch et al. (1995),

9 working in Bolivia, described concentric circles of woody, herbaceous and cryptogamic

10 vegetation, as a spatial projection of a seral process. They reported also the occurrence

11 of termite nests in shrub canopies, and postulated their role in the formation of pristine soils, but they did not identify them as wood destroyers.

\section{Conclusion}

To the light of our observations it is highly probable that climatic fluctuations and biological interactions between plants, microbes and animals, rather than invariant environmental factors such as aspect and slope, drive the cycle of change of the 'rock savanna' vegetation (Houle and Phillips, 1989). Despite variation in the species composition of vegetation patches, which we observed to occur on the same inselberg

21 according to aspect and altitude (Sarthou, 1992, 2001), a common sequence of vegetation and soil development, involving a limited number of dominant plant species, can be described (Fig. 7). Several well-known mechanisms of plant succession play probably a role in the dynamics of 'rock savanna', in particular facilitation (establishment of plant species on cyanobacterial crusts, sand deposit around 
1 Rhynchospora tufts), tolerance (establishment of C. minor within bromeliaceous mats,

2 of Myrtaceae within Clusia thickets), and small-scale disturbance (colonization of

3 cyanobacterial crusts by enchytraeids, destruction of Clusia thickets by fire, fungi and

4 termites). However, the random establishment of plant and animal species, exemplified

5 by a high turnover rate of species between seasons (Porembski et al., 2000a), vegetation

6 patches (Kounda-Kiki et al., 2004) and inselbergs (Porembski et al., 2000a; Sarthou et

7 al., 2003; Parmentier et al., 2005), should not be overlooked. The non-equilibrium co-

8 existence of a variety of organisms in a permanently changing environment (Connell,

9 1978; Briske et al., 2003) probably contributes to explain the high level of biodiversity

10 exhibited by inselbergs, despite harshness of life conditions. They may also explain why

11 so few authors attributed unambiguously to dynamic processes the wide variety of plant

12 communities observed on isolated rock outcrops (Hambler, 1964; Shure and Ragsdale,

13 1977; Houle and Phillips, 1989; Larpin et al., 2000).

14

15 Acknowledgements

16

We want to acknowledge Dr Bernard Duhem (Muséum National d'Histoire

18 Naturelle, Paris) and Dr Léonide Celini (Université Paris-XII) for the identification of

19 basidiomycetes and termites involved in the destruction of stem and branch wood of $C$.

20 minor.

21

22

References 
1 Benzécri, J.P., 1969. Statistical analysis as a tool to make patterns emerge from data. In:

Biedinger, N., Porembski, S., Barthlott, W., 2000. Vascular plants on inselbergs: vegetative and reproductive strategies. In: Porembski, S., Barthlott, W. (Eds.), Inselbergs. Biotic Diversity of Isolated Rock Outcrops in Tropical and Temperate Regions. Springer, Berlin, pp. 117-142.

Braun-Blanquet, J., 1964. Pflanzensoziologie: Grundzüge der Vegetationskunde. Springer, Wien.

Bremer, H., Sander, H., 2000. Inselbergs: geomorphology and geoecology. In: Porembski, S., Barthlott, W. (Eds.), Inselbergs. Biotic Diversity of Isolated Rock Outcrops in Tropical and Temperate Regions. Springer, Berlin, pp. 7-35.

Briske, D.D., Fuhlendorf, S.D., Smeins, F.E., 2003. Vegetation dynamics on rangelands: a critique of the current paradigms. J. Appl. Ecol. 40, 601-614.

Büdel, B., Becker, U., Follmann, G., Sterflinger, K., 2000. Algae, fungi, and lichens on inselbergs. In: Porembski, S., Barthlott, W. (Eds.), Inselbergs. Biotic Diversity of Isolated Rock Outcrops in Tropical and Temperate Regions. Springer, Berlin, pp. 69-90. 
1 Büdel, B., Becker, U., Porembski, S., Barthlott, W., 1997. Cyanobacteria and

Burbanck, M.P., Phillips, D.L., 1983. Evidence of plant succession on granite outcrops of the Georgia Piedmont. Am. Midl. Nat. 109, 95-104.

Burbanck, M.P., Platt, R.B., 1964. Granite outcrop communities of the Piedmont Plateau in Georgia. Ecology 45, 292-306.

1 Connell, J.H., 1978. Diversity in tropical rain forests and coral reefs. Science 199, 1302$2 \quad 1310$.

Descamps, M., Gasc, J.P., Lescure, J., Sastre, C., 1978. Étude des écosystèmes guyanais. II. Données biogéographiques sur la partie orientale des Guyanes. C. R. Soc. Biogéogr. 467, 55-82.

Gasc, J.P., Sarthou, C., Garrouste, R., Villiers, J.F., Cremers, G., Thiollay, J.M., 1998. Inselbergs et savanes-roches en Guyane: biodiversité et conservation des milieux associés aux affleurements granitiques. JATBA 40, 311-327.

Granville, J.J. de, Sastre, C., 1974. Aperçu sur la végétation des inselbergs du sud-ouest de la Guyane Française. C. R. Soc. Biogéogr. 439, 54-58. 
1 Greenacre, M.J., 1984. Theory and Applications of Correspondence Analysis. 2 Academic Press, London.

3

4 Gruau, G., Martin, H., Levêque, B., Capdevila, R., 1985. Rb-Sr and Sm-Nd 5 geochronology of lower proterozoic granite-greenstone terrains in French Guiana, South America. Precambr. Res. 30, 63-80.

7

8 Hambler, D.J., 1964. The vegetation of granitic outcrops in western Nigeria. J. Ecol. 52, 9 573-594.

11 Houle, G., Phillips, D.L., 1989. Seed availability and biotic interactions in granite outcrop plant communities. Ecology 70, 1307-1316.

14 Hurault, J., 1963. Recherches sur les inselbergs granitiques nus en Guyane Française. Rev. Géomorphol. Dyn. 14, 49-61.

16

Ibisch, P.L., Rauer, G., Rudolph, D., Barthlott, W., 1995. Floristic, biogeographical, and vegetational aspects of Pre-Cambrian rock outcrops (inselbergs) in eastern Bolivia. Flora 190, 299-314.

21 Isichei, A.O., Longe, A.P., 1984. Seasonal succession in a small isolated rock dome plant community in western Nigeria. Oikos 43, 17-22.

24 Jeník J., Hall J.B., 1976. Plant communities of the Accra plains, Ghana. Folia Geobot. Phytotaxonom. 11, 163-212. 
2 Keever, C., Oosting, H.J., Anderson, L.E., 1951. Plant succession on exposed granite of

6 Kounda-Kiki, C., Ponge, J.F., Mora, P., Sarthou, C., 2008. Humus profiles and 7 Rocky Face Mountain, Alexander County, North Carolina. Bull. Torrey Bot. Club 78, 401-421. successional development in a rock savanna: a micromorphological approach pointing to fire as a disturbance event (Nouragues inselberg, French Guiana). Pedobiologia (in press).

Kounda-Kiki, C., Vaçulik, A., Ponge, J.F., Sarthou, C., 2004. Soil arthropods in a developmental succession on the Nouragues inselberg (French Guiana). Biol. Fertil. Soils 40, 119-127.

Kounda-Kiki, C., Vaçulik, A., Ponge, J.F., Sarthou, C., 2006. Humus profiles under main vegetation types in a 'rock savanna' (Nouragues inselberg, French Guiana). Geoderma 136, 819-829.

Larpin, D., 2001. The low forest (Nouragues inselberg). In: Bongers, F., CharlesDominique, P., Forget, P.M., Théry, M. (Eds.), Nouragues. Dynamics and PlantAnimal Interactions in a Neotropical Rainforest. Kluwer, Dordrecht, pp. 47-63.

Larpin, D., Sarthou, C., Tardy, C., 2000. Dynamique de la végétation sur l'inselberg des Nouragues (Guyane française) à différentes échelles de temps (pluriannuelle à 
4 Leach, W., 1931. On the importance of some mosses as pioneers on unstable soils. J. 5

6

7 Meirelles, S.T., Pivello, V.R., Joly, C.A., 1999. The vegetation of granite rock outcrops 8

plurimillénaire). In: Servant, M., Servant-Vildary, S. (Eds.), Dynamique à Long Terme des Écosystèmes Forestiers Intertropicaux. UNESCO, Paris, pp. 189-197. Ecol. 19, 98-102. in Rio de Janeiro, Brazil, and the need for its protection. Environ. Protect. 26, $10-20$.

Oosting, H.J., Anderson, L.E., 1939. Plant succession on granite rock in Eastern North Carolina. Bot. Gaz. 100, 750-768.

Oumorou, M., Lejoly, J., 2003. Écologie, flore et végétation de l'inselberg Sobakpérou (Nord-Bénin). Acta Bot. Gallica 150, 65-84.

Parmentier, I., 2001. Premières études sur la diversité végétale des inselbergs de Guinée Équatoriale continentale. Syst. Geogr. Plants 71, 911-922.

Parmentier, I., 2003. Study of the vegetation composition in three inselbergs from continental equatorial Guinea (western Central Africa): effects of site, soil factors and position relative to forest fringe. Belgian J. Bot. 136, 63-72.

4 Parmentier, I., 2005. Ecology and distribution of Melastomataceae in African rain forest inselbergs. Biotropica 37, 364-372. 
2 Parmentier, I., Stévart, T., Hardy, O.J., 2005. The inselberg flora of Atlantic Central Africa. I. Determinants of species assemblages. J Biogeogr. 32, 685-696.

4

5 Peltier, A., Touzet, M.C., Armengaud, C., Ponge, J.F., 1997. Establishment of Fagus sylvatica and Fraxinus excelsior in an old-growth beech forest. J. Veg. Sci. 8, $13-20$.

8

9 Porembski, S., Becker, U., Seine, R., 2000a. Islands on islands: habitats on inselbergs. In: Porembski, S., Barthlott, W. (Eds.), Inselbergs. Biotic Diversity of Isolated Rock Outcrops in Tropical and Temperate Regions. Springer, Berlin, pp. 49-67.

Porembski, S., Mund, J.P., Szarzinski, J., Barthlott, W., 1996. Ecological conditions and floristic diversity of an inselberg in the savanna zone of Ivory Coast: Mt Niangbo. In: Guillaumet, J.L., Belin, M., Puig, H. (Eds.), Phytogéographie Tropicale: Réalités et Perspectives. ORSTOM, Paris, pp. 251-261.

Porembski, S., Seine, R., Barthlott, W., 2000b. Factors controlling species richness of inselbergs. In: Porembski, S., Barthlott, W. (Eds.), Inselbergs. Biotic Diversity of Isolated Rock Outcrops in Tropical and Temperate Regions. Springer, Berlin, pp. $452-481$.

Sarthou, C., 1992. Dynamique de la Végétation Pionnière sur un Inselberg en Guyane Française. Doctorate thesis, Pierre-et-Marie-Curie University, Paris. 
1 Sarthou, C., 2001. Plant communities on a granitic outcrop. In: Bongers, F., CharlesDominique, P., Forget, P.M., Théry, M. (Eds.), Nouragues. Dynamics and PlantAnimal Interactions in a Neotropical Rainforest. Kluwer, Dordrecht, pp. 65-78.

Sarthou C., Grimaldi, C., 1992. Mécanismes de colonisation par la végétation d'un inselberg granitique en Guyane Française. Rev. Écol. Terre Vie 47, 329-349.

Sarthou, C., Thérézien, Y., Couté, A., 1995. Cyanophycées de l'inselberg des Nouragues. Nova Hedwigia 61, 85-109.

Sarthou, C., Villiers, J.F., 1998. Epilithic plant comunities on inselbergs in French Guiana. J. Veg. Sci. 9, 847-860.

Sarthou, C., Villiers, J.F., Ponge, J.F., 2003. Shrub vegetation on tropical granitic inselbergs in French Guiana. J. Veg. Sci. 14, 645-652.

Shure, D.J., Ragsdale, H.L., 1977. Patterns of primary succession on granite outcrop surfaces. Ecology 58, 993-1006.

Théveniaut, H., Delor, C., 2004. Connaissance Géologique de la Guyane. Livret de l’Enseignant. BRGM, Cayenne.

Vaçulik, A., Kounda-Kiki, C., Sarthou, C., Ponge, J.F., 2004. Soil invertebrate activity in biological crusts on tropical inselbergs. Eur. J. Soil Sci. 55, 539-549. 
1 Van der Maarel, E., 1979. Transformation of cover-abundance values in phytosociology and its effects on community similarity. Vegetatio $39,97-114$.

3

4 Watt, A.S., 1955. Bracken versus heather, a study in plant sociology. J. Ecol. 43, 4905 506.

6

7 Whitehouse, E., 1933. Plant succession on central Texas granite. Ecology 14, 391-405. 
1

Table 1. List of plant species which were sampled on the Nouragues inselberg, together with their codes for CA and potential life forms

\begin{tabular}{|c|c|c|c|}
\hline Code & Species & Family & Life form \\
\hline$\overline{\mathrm{APE}}$ & Actinostachys pennula (O.P. Swartz) W.J. Hooker and J.G. Baker & Schizaeaceae & Erect perennial herb \\
\hline AAQ & Aechmea aquilega (Salisbury) Grisebach & Bromeliaceae & Rosette \\
\hline AME & Aechmea melinonii Hooker & Bromeliaceae & Rosette \\
\hline APU & Aganisia pulchella Lindley & Orchidaceae & Climber herb \\
\hline AJE & Anthurium jenmanii Engler & Araceae & Erect perennial herb \\
\hline ARA & Axonopus ramosus Swallen & Poaceae & Erect perennial herb \\
\hline $\mathrm{BCA}$ & Borreria capitata (Ruiz et Pavon) de Candolle & Rubiaceae & Suffrutex \\
\hline BUC & Burmannia capitata (Walter ex Gmelin) Martius & Burmanniaceae & Annual \\
\hline CBE & Catopsis berteroniana (Schultes f.) Mez & Bromeliaceae & Rosette \\
\hline CCA & Cavendishia callista Donnell-Smith & Ericaceae & Woody climber \\
\hline $\mathrm{CDE}$ & Chamaecrista desvauxii (Colladon) Killip var. saxatilis (Amshoff) Irwin et Barneby & Caesalpiniaceae & Suffrutex \\
\hline CAL & Chelonanthus alatus (J.B. Aublet) Pulle & Gentianaceae & Erect perennial herb \\
\hline CPU & Chelonanthus purpurascens (J.B. Aublet) Struwe, S. Nilsson and V.A. Albert & Gentianaceae & Erect perennial herb \\
\hline CRO & Cleistes rosea Lindley & Orchidaceae & Erect perennial herb \\
\hline CMI & Clusia minor Linnaeus & Clusiaceae & Shrub \\
\hline CNE & Clusia nemorosa G.F.W. Meyer & Clusiaceae & Shrub \\
\hline CRU & Commelina rufipes Seubert var. glabrata (D.R. Hunt) Faden et D.R. Hunt & Commelinaceae & Creeping perennial herb \\
\hline CLA & Coussapoa latifolia Aublet & Cecropiaceae & Tree \\
\hline $\mathrm{CHO}$ & Croton hostmannii Miquel & Euphorbiaceae & Shrub \\
\hline CBL & Cuphea blackii Lourteig & Lythraceae & Suffrutex \\
\hline CGU & Cybianthus guianensis (de Candolle) Miquel subsp. pseudoicacoreus (de Candolle) Agostini & Myrsinaceae & Tree \\
\hline EGR & Encyclia granitica (Lindley) Schlechter & Orchidaceae & Erect perennial herb \\
\hline EIO & Encyclia ionosma (Lindley) Schlechter & Orchidaceae & Erect perennial herb \\
\hline ENO & Epidendrum cf. nocturnum N.J. Jacquin & Orchidaceae & Erect perennial herb \\
\hline ESU & Eriotheca surinamensis (Uittien) A. Robyns & Bombacaceae & Tree \\
\hline ECO & Ernestia confertiflora Wurdack & Melastomataceae & Suffrutex \\
\hline EGI & Ernestia granvillei Wurdack & Melastomataceae & Shrub \\
\hline ECI & Erythroxylum citrifolium Saint-Hilaire & Erythroxylaceae & Shrub \\
\hline GLI & Guzmania lingulata (Linnaeus) Mez & Bromeliaceae & Rosette \\
\hline IAN & Ipomoea angulata Martius ex Choisy & Convolvulaceae & Climber herb \\
\hline IPU & Irlbachia purpurescens (Aublet) Maas & Gentianaceae & Erect perennial herb \\
\hline MCR & Macrocentrum cristatum (de Candolle) Triana & Melastomataceae & Suffrutex \\
\hline MSA & Matelea sastrei Morillo & Asclepiadaceae & Climber herb \\
\hline MCI & Miconia ciliata (L.C. Richard) de Candolle & Melastomataceae & Shrub \\
\hline MFA & Myrcia fallax (L.C. Richard) de Candolle & Myrtaceae & Shrub \\
\hline MGU & Myrcia guianensis (Aublet) de Candolle & Myrtaceae & Shrub \\
\hline MSS & Myrcia saxatilis (Amshoff) Mc Vaugh & Myrtaceae & Shrub \\
\hline MSY & Myrcia silvatica (G.F.W. Meyer) de Candolle & Myrtaceae & Shrub \\
\hline MSP & Myrciaria sp. Desvaux & Myrtaceae & Tree \\
\hline NFL & Neea floribunda Poeppig et Endlicher & Nyctaginaceae & Shrub \\
\hline POY & Paepalanthus oyapokensis Herzog & Eriocaulaceae & Annual \\
\hline PRI & Panicum rivale Swallen & Poaceae & Erect perennial herb \\
\hline PHI & Perama hirsuta Aublet & Rubiaceae & Annual \\
\hline PLI & Phragmipedium lindleyanum (Schomburgk) Rolfe & Orchidaceae & Erect perennial herb \\
\hline PPY & Phtirusa pyrifolia (Humboldt, Bonpland et Kunth) Eichler & Loranthaceae & Hemiparasite \\
\hline PSC & Piptocoma schomburgkii (Schultz Bipontinus) Pruski & Asteraceae & Shrub \\
\hline PGE & Pitcairnia geyskesii L.B. Smith & Bromeliaceae & Rosette \\
\hline PAD & Polygala adenophora de Candolle & Polygalaceae & Annual \\
\hline PRE & Psittacanthus redactus Rizzini & Loranthaceae & Hemiparasite \\
\hline PHO & Psychotria hoffmannseggiana (Roemer et Schultes) Müller-Argoviensis & Rubiaceae & Shrub \\
\hline RSP & Racinea spiculosa (Grisebach) Spencer et L.B. Smith & Bromeliaceae & Rosette \\
\hline RBA & Rhynchospora barbata (Vahl) Kunth & Cyperaceae & Erect perennial herb \\
\hline RCE & Rhynchospora cephalotes (Linnaeus) Vahl & Cyperaceae & Erect perennial herb \\
\hline RFA & Rhynchospora fallax Uittien & Cyperaceae & Erect perennial herb \\
\hline RSU & Rhynchospora subdicephala Koyama & Cyperaceae & Erect perennial herb \\
\hline RTE & Rhynchospora tenella (C.G.D. Nees) Böckeler & Cyperaceae & Erect perennial herb \\
\hline RCR & Rudgea crassiloba (Bentham) B.L. Robinson & Rubiaceae & Shrub \\
\hline SCE & Satyria cerander (Dunal) A.C. Smith & Ericaceae & Woody climber \\
\hline SAL & Sauvasegia aliciae Sastre & Ochnaceae & Suffrutex \\
\hline SCY & Scleria cyperina Kunth & Cyperaceae & Erect perennial herb \\
\hline SPR & Selaginella producta Baker & Selaginellaceae & Creeping perennial herb \\
\hline SPA & Sipanea pratensis Aublet & Rubiaceae & Suffrutex \\
\hline SGU & Souroubea guianensis Aublet & Marcgraviaceae & Woody climber \\
\hline SSU & Stelestylis surinamensis Harling & Cyclanthaceae & Erect perennial herb \\
\hline SPS & Sterculia pruriens K. Schumann & Sterculiaceae & Tree \\
\hline SGU & Stylosanthes guianensis (Aublet) Swartz & Fabaceae & Suffrutex \\
\hline TCA & Tabebuia capitata (Bureau et K. Schumann) Sandwith & Bignoniaceae & Tree \\
\hline TDE & Ternstroemia dentata (Aublet) Swartz & Theaceae & Tree \\
\hline UAM & Utricularia amethystina Saint-Hilaire & Lentibulariaceae & Annual \\
\hline $\mathrm{UCH}$ & Utricularia choristotheca P. Taylor & Lentibulariaceae & Annual \\
\hline UHI & Utricularia hispida Lamarck & Lentibulariaceae & Annual \\
\hline USU & Utricularia subulata Linnaeus & Lentibulariaceae & Annual \\
\hline VPL & Vriesea pleiosticha (Grisebach) Gouda & Bromeliaceae & Rosette \\
\hline VSP & Vriesea splendens (Brongniart) Lemaire & Bromeliaceae & Rosette \\
\hline
\end{tabular}




\section{Legends for figures}

2

3 Figure 1. Map of French Guiana, indicating the localization of inselbergs (modified 4 5

$6 \quad$ Figure 2. after Descamps et al. (1978))

7

8

Terrasses')

\begin{abstract}
A South overview of the 'rock savanna' on the Nouragues inselberg, showing the summit plateau (called 'Summit'), the cliff and the lower terrace (called 'Les
\end{abstract} B A young ramet of Clusia minor, surrounded by Pitcairnia geyskesii. Note the adventitious development of C. minor on the right side of the photo C An advancing destruction zone in a Clusia thicket (advance from left to right). In the right part, dead wood has been already transformed into humus, now covered with mosses, while branches of $C$. minor are still living on the left, with fallen wood and standing dead wood as intermediates

D A macro-view of the wood of C. minor, infested by the basidiomycete Lentinus gr. villosus (see sporocarp), then colonized by a termite society (Nasutitermes). Note the deposition of wood transformed into excrements along the branches, bark being not or only poorly consumed E A destruction zone now colonized by a variegated flora, dominated by saplings of the shrub Ernestia granvillei. Note the absence of litter from Clusia minor, dead roots of this species being apparent at the ground surface, indicating erosion of the accumulated humus

F A destruction zone now partly colonized by mosses (foreground), herbaceous species (Pitcairnia geyskesii, Scleria cyperina) and woody species (Myrtaceae) 
$1 \quad$ Figure 3. Total correspondence analysis

A Projection of samples and passive variables (growth forms, sites, slope classes, species richness) in the plane of the first two axes B Projection of active variables (plant species) in the plane of the first two axes

Figure 4. Relationships between cover values (Van der Maarel scale) of Pitcairnia geyskesii and Clusia minor in patches of 'rock savanna' on slopes. Black dot size is proportional to the number of superposed samples (from 1 to 9 )

Figure 5. Four stages of the seral development of Clusia minor thickets on moderate slopes (modified after Sarthou (1992))

Figure 6. Three stages of the development of vegetation and sediments in granite depressions (modified after Sarthou 1992). Arrows indicate the advance of sand deposits

Figure 7. Successional relationships between main vegetation types of the rock savanna' on slopes and depressions, and the parallel development of (organic) soils and (mineral) sediments 


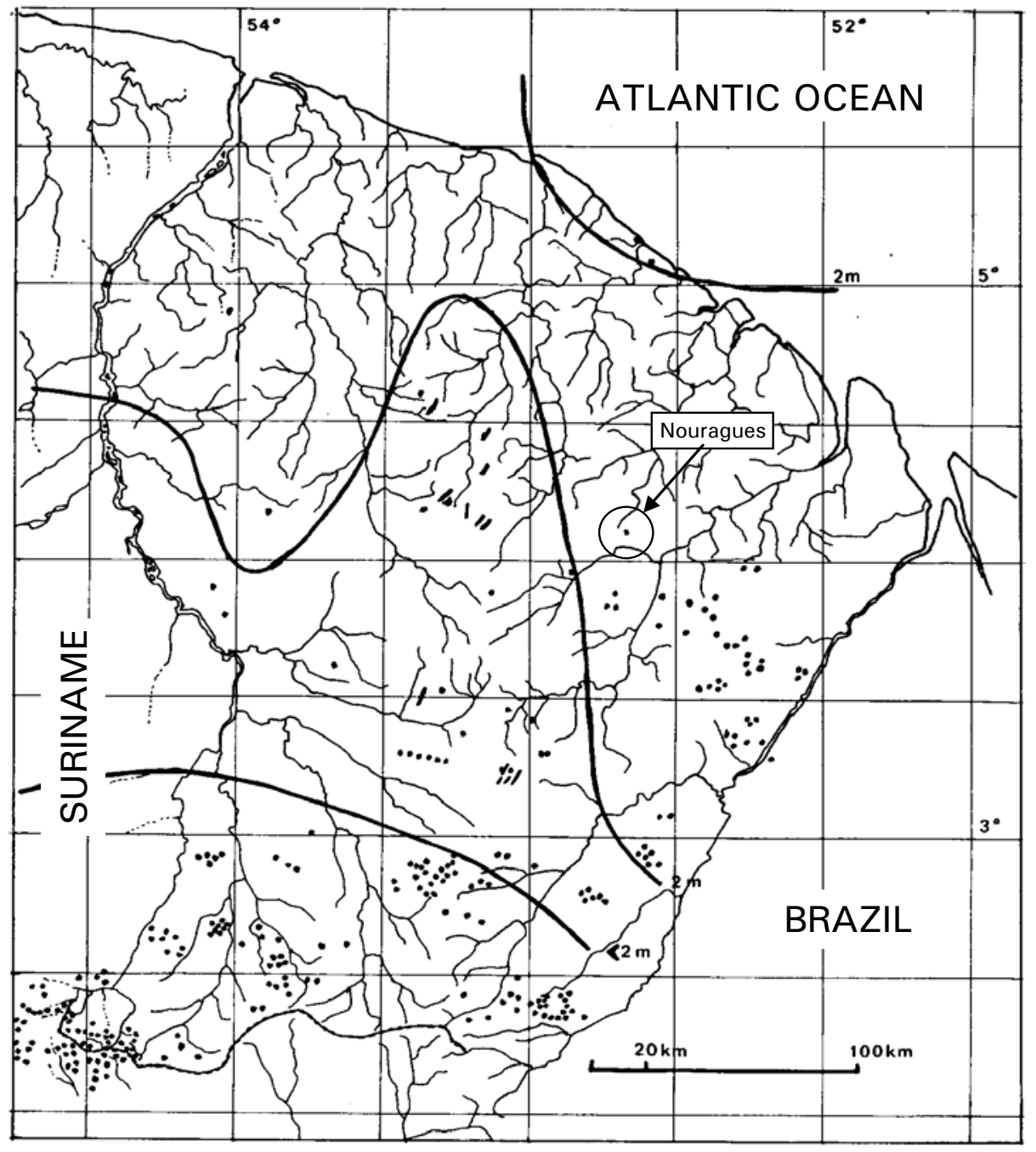

2 Fig. 1. 

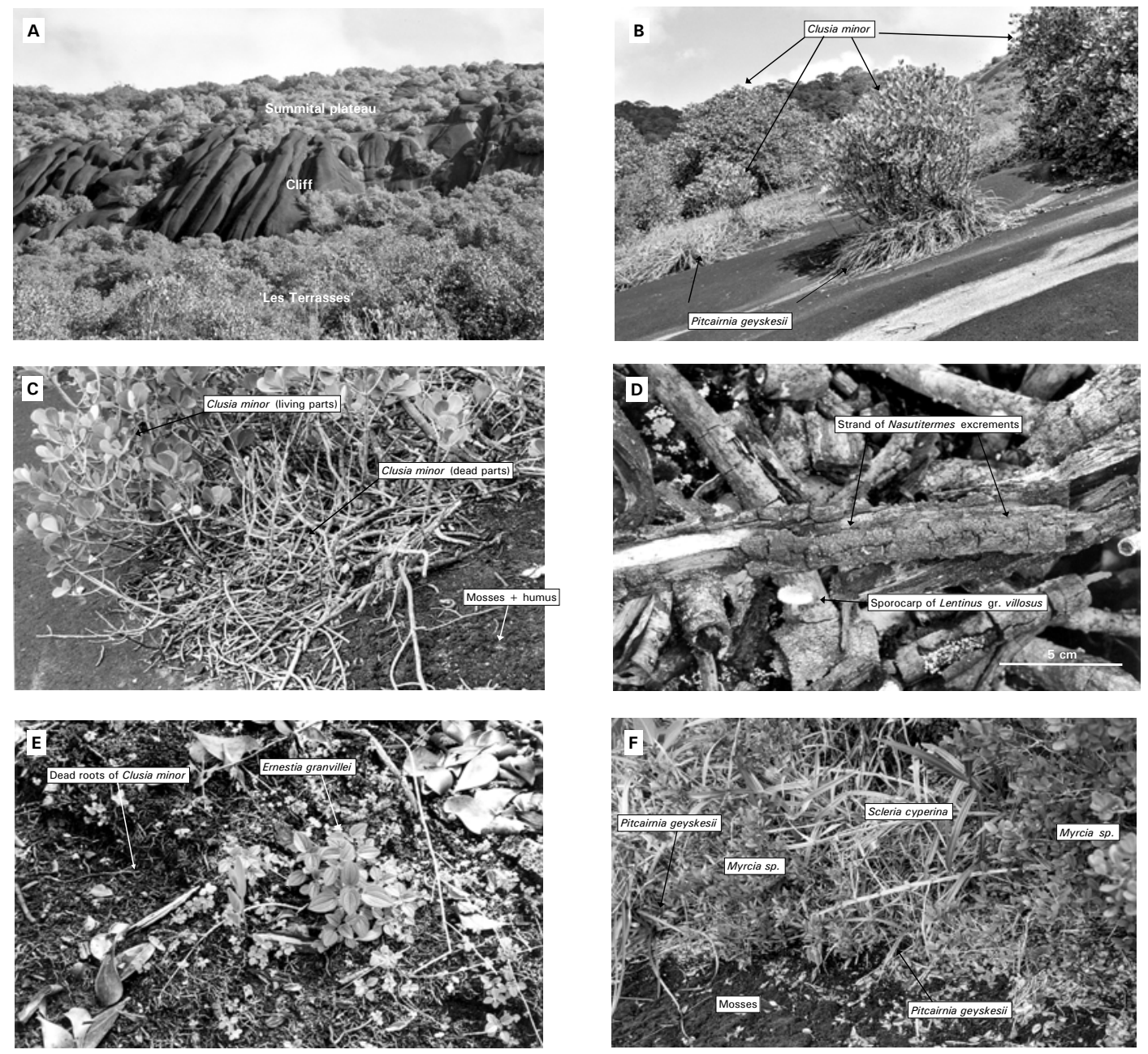

Fig. 2. 
A

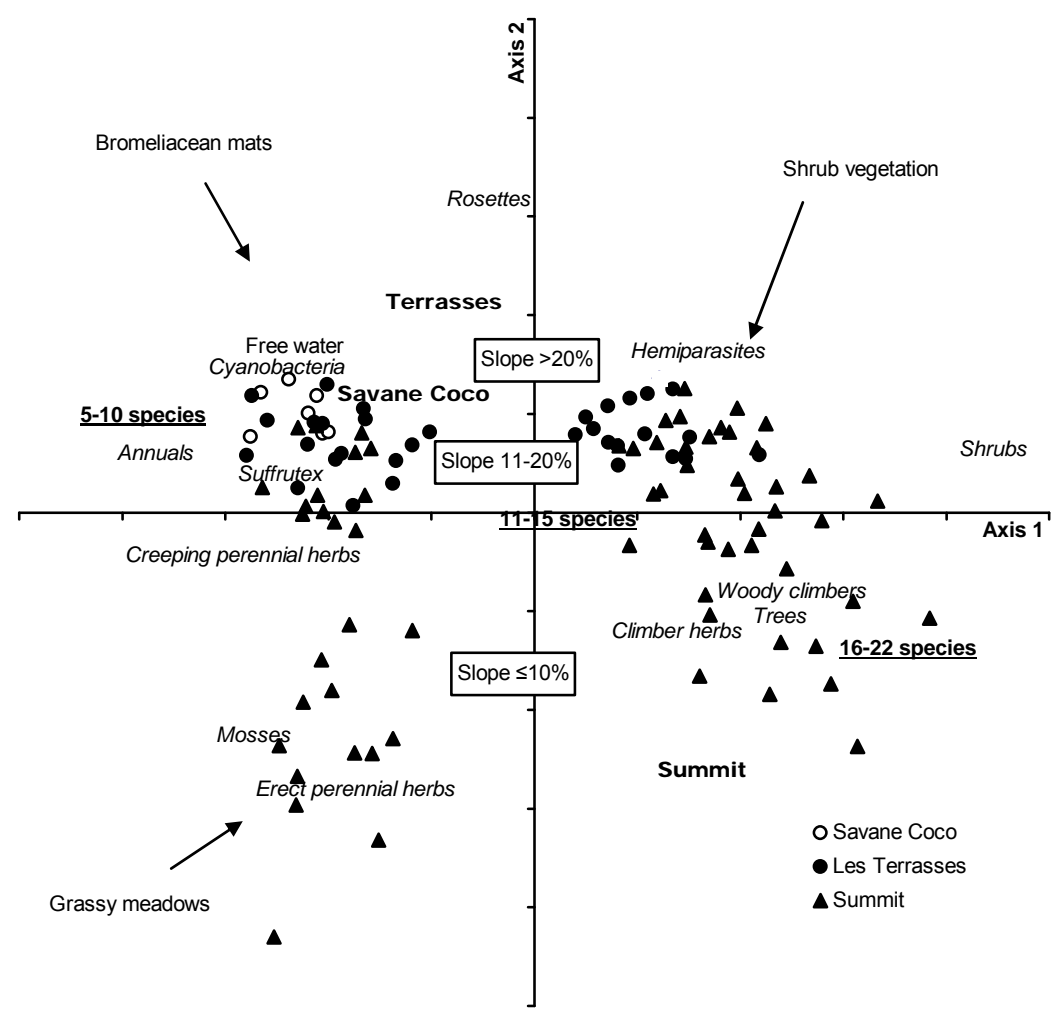

B

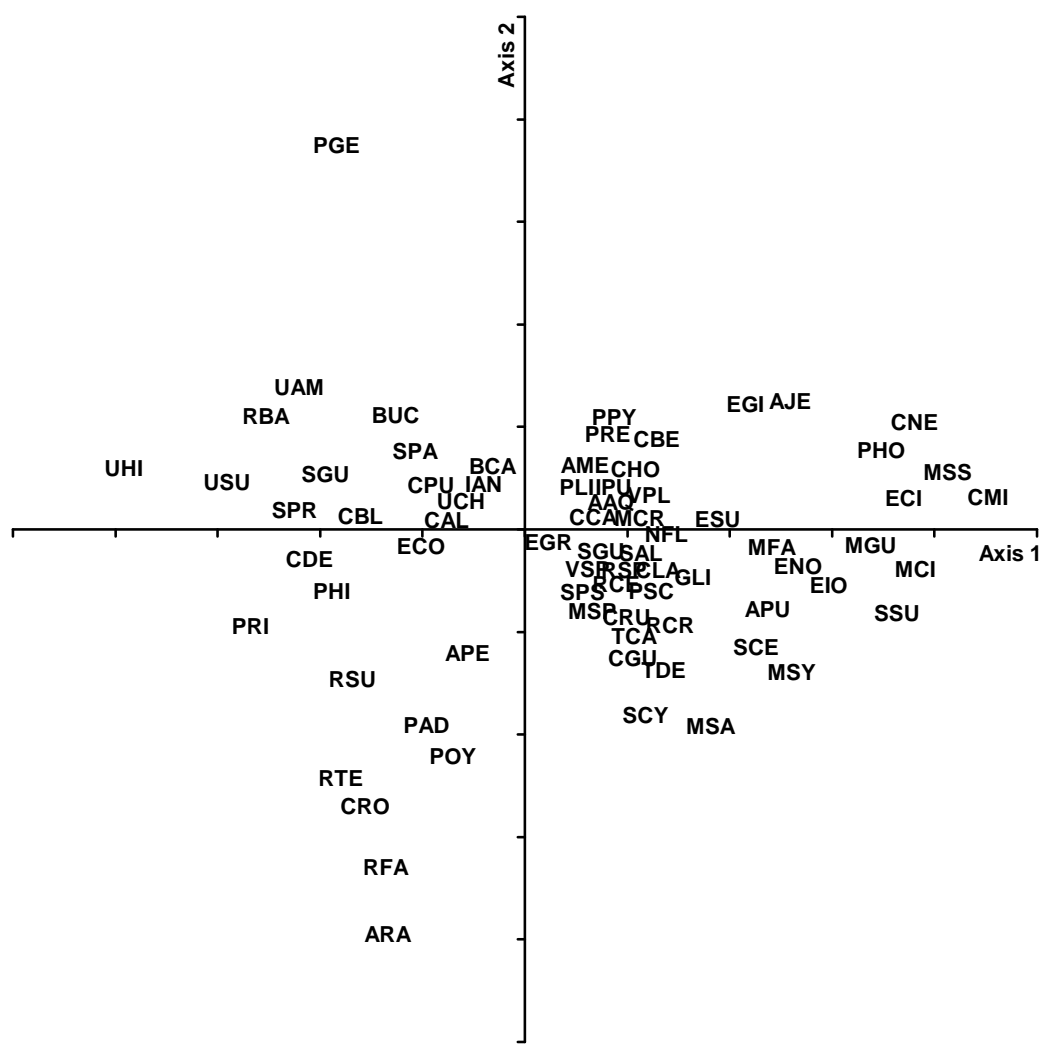

$3 \quad$ Fig. 3 
1

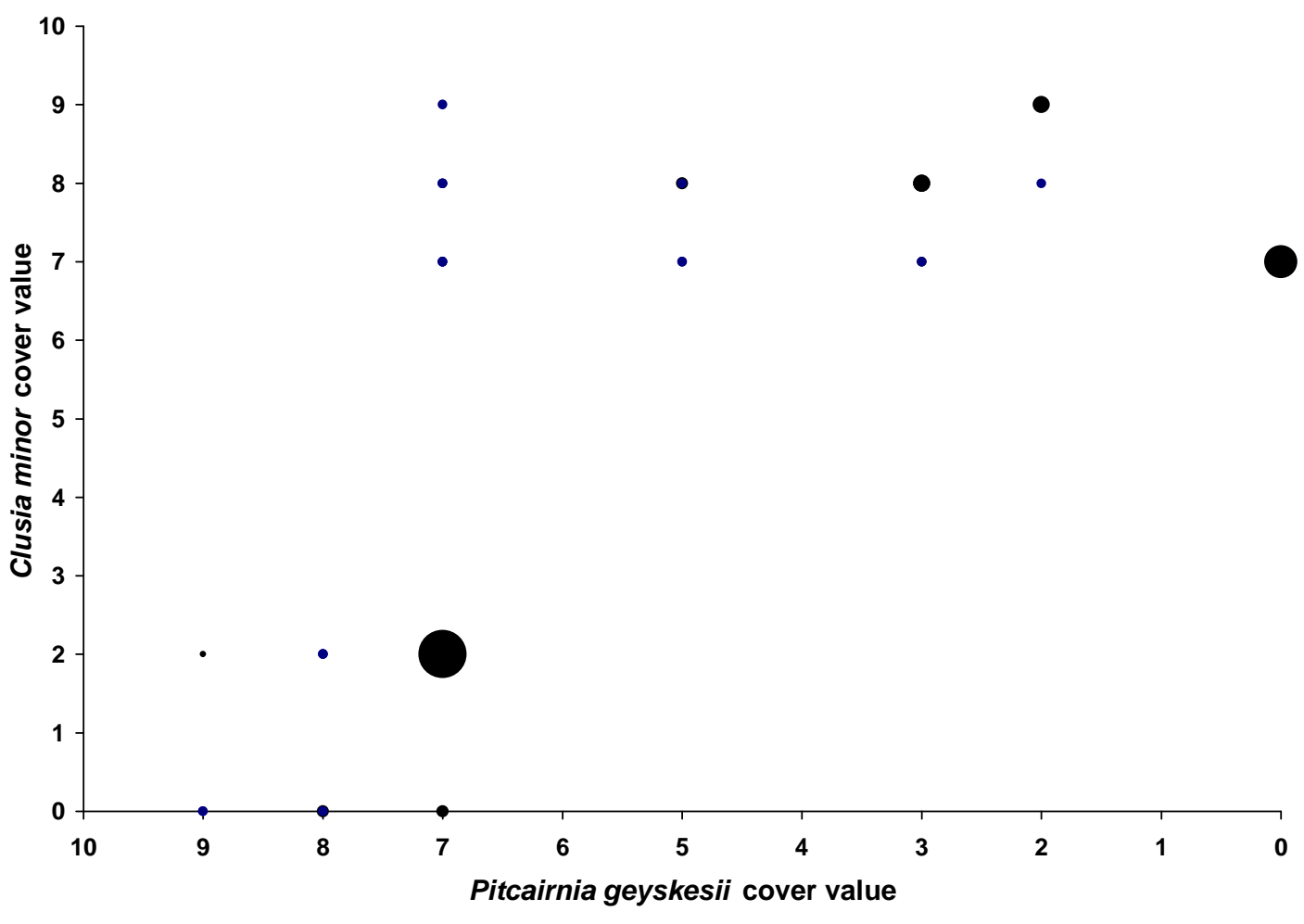

$3 \quad$ Fig. 4 

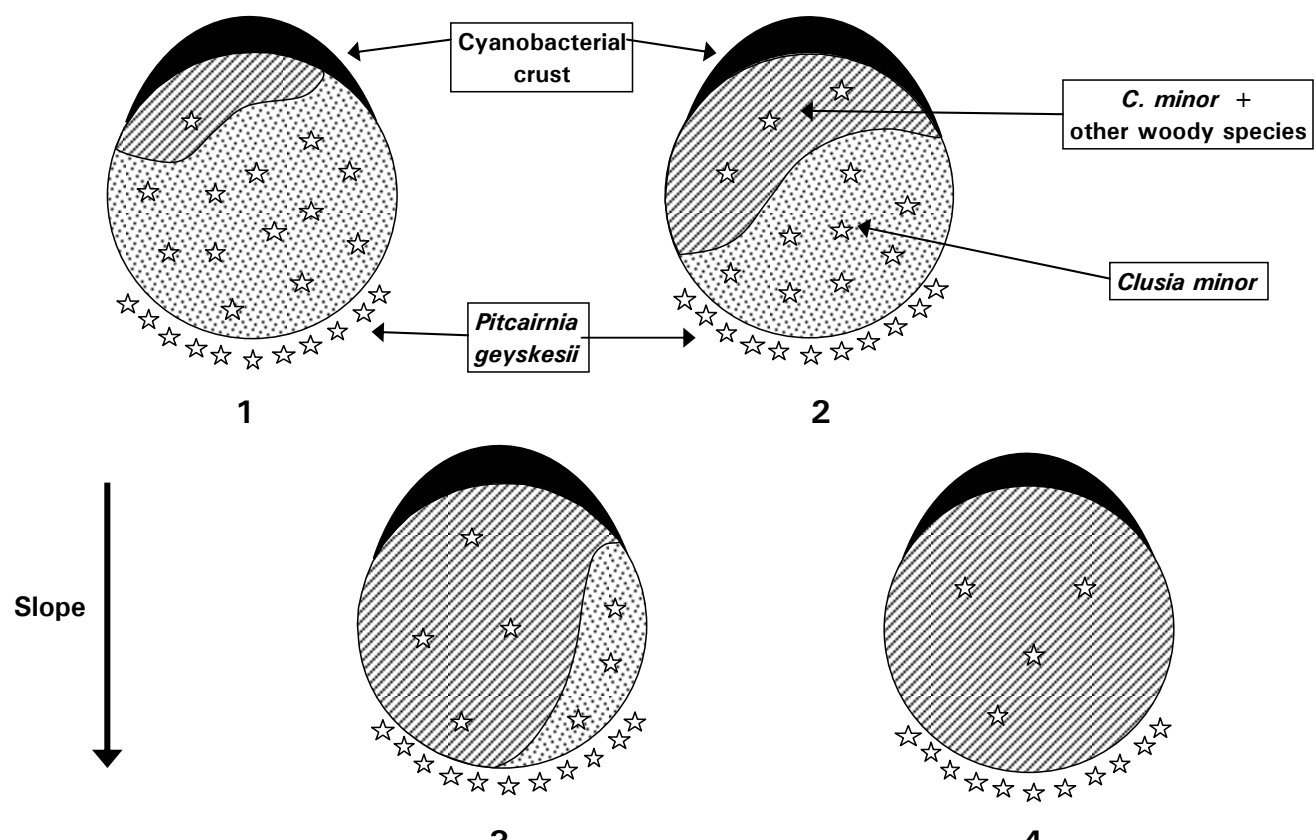

3

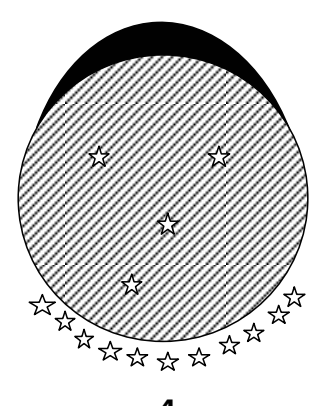

1

2 Fig. 5 


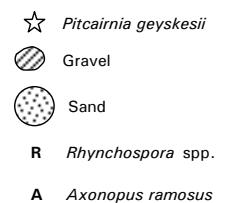

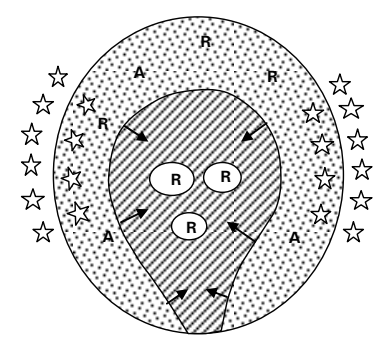

1

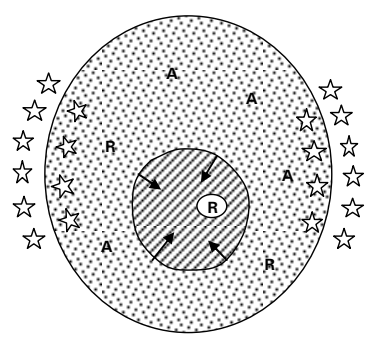

2

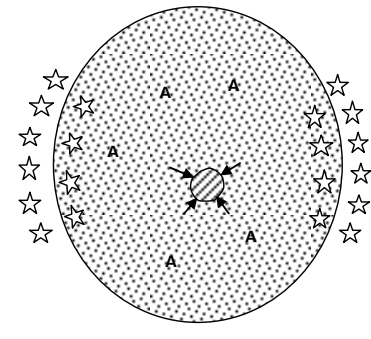

3

2 Fig. 6 

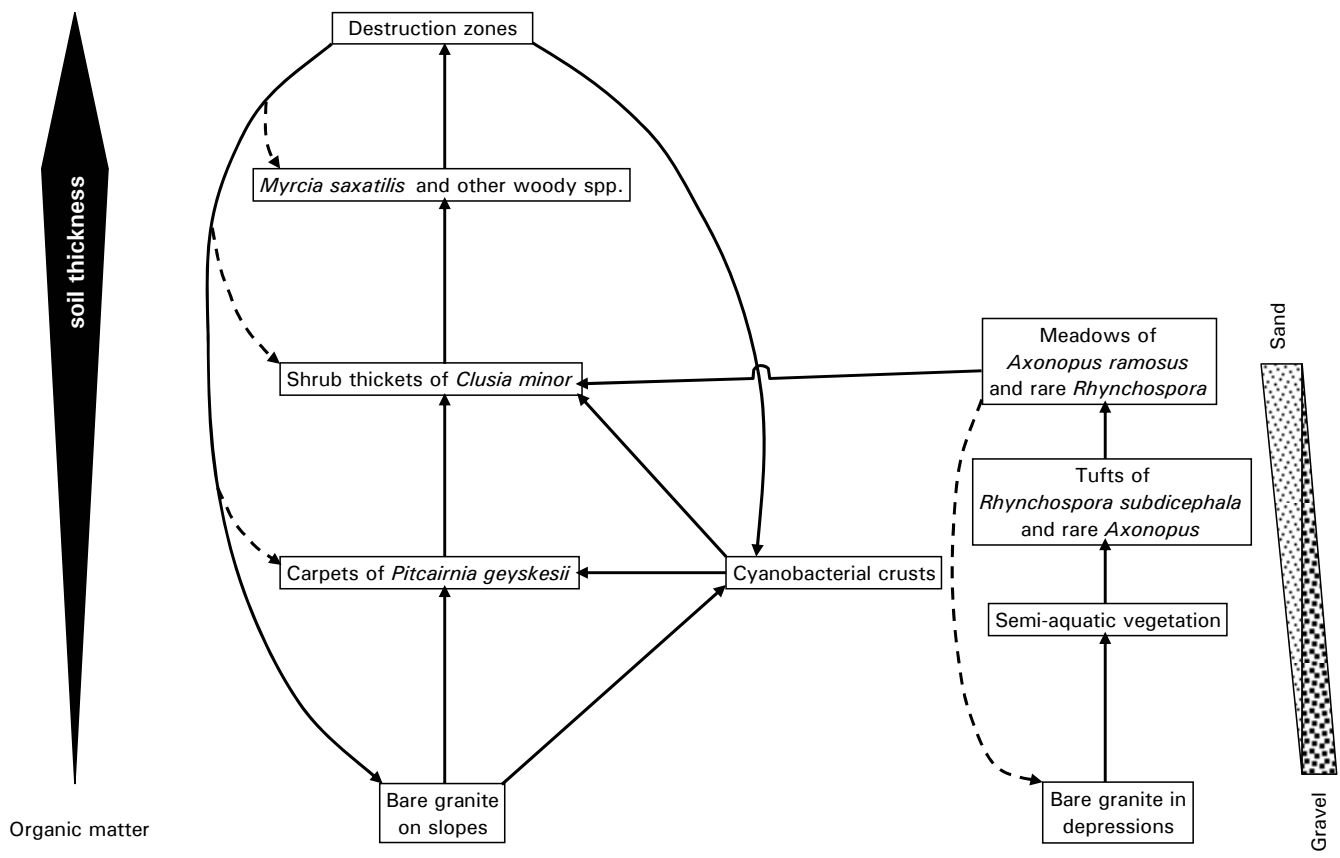

$\begin{array}{ll}2 & \text { Fig. } 7\end{array}$ 